\title{
Distance learning of primary school students in the assessment of parents
}

\author{
Zoya Proshkova* \\ Sociological Institute of the Federal Center of Theoretical and Applied Sociology of the Russian \\ Academy of Sciences, Russia, Saint Petersburg, Russia
}

\begin{abstract}
This article presents the results of a survey of parents about distance learning of their children, primary school children, during quarantine. In a sociological study, interviews were conducted with families of third grade students from St. Petersburg schools. The answers to the questions were processed using the Russian computer program "Discant". As a result of the analysis, six leading thematic leitmotifs for a story about a new educational experience were identified. It was found that the main disadvantages of distance learning are considered by the parents to be the load on the schoolchild's family, the large expenditure of time, and the discrepancy between teaching methods and the child's age. According to parents, the advantages of distance education are safety, comfortable schedule, digital educational technologies. Conclusions of the project are the preference of a mixed format for teaching primary school children during quarantine. An empirical research perspective analyzes parental investment in children's education.
\end{abstract}

\section{Distance learning of primary school students in pandemic conditions}

In the spring of 2020, quarantine was introduced at schools in St. Petersburg due to the coronavirus epidemic. Schoolchildren, including primary school students, were transferred to distance learning. If we look at the situation in terms of the methodology of sociological research, an experiment was carried out in natural conditions, with the help of which it is possible to study the effectiveness of distance educational methods [1]. One of the sources of reliable information about the results of the experiment is interviews with the parents of the students, since the family observed the educational process and actively participated in it.

The study presented in the article analyzes family assessments of distance learning for schoolchildren. The target audience was elementary school students and their parents. We were interested in the opinion of fathers and mothers, grandfathers and grandmothers, the closest family environment of the child about the educational experience he had met. It is important to establish which of the informants is ready in the future to choose online education for their children in schools and further educational paths [2], and also to study

\footnotetext{
${ }^{*}$ Corresponding author: eder57@yandex.ru
} 
family investments in distance education of primary school students, in particular the time spent on helping children in preparing homework, mastering the program [3].

In addition, the project set a methodological task of assessing the relevance of computer programs in the study of materials of unstructured interviews [4]. Conversations with parents were free-form texts. The processing of this type of primary sociological information is much more difficult than the analysis of answers to the questions of a formalized questionnaire.

\section{Interviews with parents of elementary school students}

In May 2020, distance interviews were conducted with parents and other close relatives of students in the two thirds grades from two regular schools in St. Petersburg. Both schools were profession-oriented, with intensive training in the English language. We assumed that when choosing a school, the parents of students relied not only on the territorial proximity of the educational institution, but also on the quality of education and the reputation of the school. This hypothesis was confirmed, the results of the survey showed the high value of the education and erudition of the informants.

The method of collecting information can be called family interviewing, since the conversation was carried out with the help of the Zoom program, and during the interview it was possible to interview not one, but several representatives of the family [5]. Not all parents agreed to participate in the sociological survey. The reasons were different: lack of time, inability to use computer survey programs, lack of interest in the results of the project, and some others. The parents who agreed to talk about the child's learning during the quarantine, in turn, wanted to get feedback from sociologists, that is, to learn about the final findings of the study.

The interview lasted from half an hour to two hours. We asked questions about how the child's school day is organized, how the lessons are conducted, how the school provides students with homework, whether digital teaching methods were used. They asked about the advantages and disadvantages of distance learning. In addition, we discussed with family, which of the parents and relatives helps the child to cope with his studies in a difficult period. Questions were asked about the educational route of children, the attitude of parents to online schools, their readiness to use innovative educational technologies in the future, since we are studying the development of distance education in Russia [6].

One of the interview blocks was based on questions about parental investments in the education of children during quarantine. We talked about the time spent on teaching the child, as well as the cost of educational services, including the payment of tutors. In particular, it studied in detail how much time each parent and other relatives spare to help the child with homework. It turns out that family support for distance learning of young students is given not only by parents and grandparents. The circle of relatives included older brothers and sisters who also studied at school distantly. Such informants in our sample turned out to be students in grades 9-11, that is, high school students. They did well with their own online lessons and distance homework and became an essential family resource for younger children.

Another set of interview questions related to extracurricular activities with children. We thought that hobby groups and lessons with tutors were canceled during the pandemic. As it turned out, paid classes, in addition to choreography and sports sections, went online. Moreover, contrary to hypotheses about the low effectiveness of distance learning for elementary school students, online classes were highly rated by parents. Thus, distance learning of foreign languages in small groups took place under the full control of the family, and there was an opportunity to help children during the lesson to follow the completion of homework. 
The interview was carried out in several ways. In the simplest situations, the sociologist spoke with one informant one-on-one, without involving other family members and the need to continue the conversation at another time. In 12 cases, the individual interview turned into a focus group of 3-4 people, as family representatives gathered at the monitor and jointly answered the sociologist's questions. Many new topics arose in the course of the collective survey, which were subsequently included in the interview guide. For example, the level of computer equipment and family literacy required to provide online classes for primary school students or the independence of the child when doing homework in digital format, as well as the benefits of online classes with a tutor were discussed.

Another option for interviewing was a conversation with the same informant, but with breaks for several hours or a day or two. This was due to the employment of the parent, who worked distantly, or the desire of the respondents to better prepare for a conversation with a sociologist. For example, five mothers from the sample drew up a detailed schedule for the education of the child under quarantine and independently calculated the family time spent on the education of their children in a changed situation. A similar type of renewed interviewing was used in the domestic sociological project of V.G. Vinogradskiy "Peasant chronicles" [7]. The difference is that rural residents were not interviewed remotely, but directly, recording the answers of the informants by hand.

An interesting way of collecting sociological information turned out to be alternating interviews with representatives of the same family. It was not always possible to conduct a collective survey of parents and grandparents. The interlocutors can interfere with each other by too active argument and defending their own point of view. In such cases, the family agreed to the researcher's proposal to speak with each informant separately, on the same day or on different days, convenient for the respondents. The interview was protracted, but it was possible to get a thorough understanding of the distribution of the family load while the child was under quarantine and distance learning [8].

The answers obtained in the course of interviewing parents were represented by arrays of unstructured primary data. With the help of the Russian computer program Discant, it was possible to identify the main thematic leitmotifs of the texts. Discant, a dialogue system for the classification and analysis of texts, was developed by Russian researchers G.I. Saganenko and E.A. Kanevsky [9]. This program is specifically designed for in-depth study of qualitative sociological research materials. It is most suitable for answering open-ended questions of the questionnaire [10].

In addition, with the help of Discant, you can study biographical essays, interview materials, the media. It was possible for several times to apply Discant to comprehend the recordings of focus groups, that is, group interviews in sociological projects of educational problems [11]. The program allows you to find the most important topics of the texts, to single out the semantic segments of the statements of the informants, to classify the elements of the text in various ways, to conduct a qualitative and quantitative analysis of the primary data of sociological research. When classifying the content of texts, the frequency of the received phrases or the topics covered is counted. An electronic database allows you to quantify any statement according to one or several criteria. For example, the field "Advantages of distance education for primary school students" in interview No. 8 looks like this: "But then we were not worried about the child getting sick" (1 - a positive assessment of education).

In total, there were 23 fields in the database with interview materials. 16 of them were textual, 7 contained socio-demographic information about the families that participated in the interview. 56 families were interviewed, giving a total of 72 interviews, since in 16 cases several representatives of the family took part in the interviews separately from each other. 


\section{Family assessment of distant learning for primary school students}

An analysis of thematic leitmotifs in the texts of family interviews showed that parents are eager to tell the story of the quarantine of younger schoolchildren, focusing on the advantages and disadvantages of distance learning. It was found what problems worried the family to the maximum extent and which ones went almost unnoticed. The most difficult collisions were described in detail. The investments that parents had to make in the education of their children have come to light. Interesting conclusions were obtained about the distribution of family responsibilities during quarantine, the educational load on various family members, and the participation of their brothers and sisters in the education of younger schoolchildren.

Table 1. Advantages and disadvantages of distance learning in the assessment of parents.

\begin{tabular}{|c|c|c|c|c|}
\hline № & $\begin{array}{c}\text { Themati } \\
\mathrm{c} \\
\text { leitmotif } \\
\mathrm{s}\end{array}$ & Types of judgments & $\begin{array}{c}\text { Numb } \\
\text { er of } \\
\text { judgm } \\
\text { ents }\end{array}$ & $\begin{array}{l}\text { Attent } \\
\text { ion } \\
\text { volum } \\
\text { e (\%) }\end{array}$ \\
\hline 1 & Time & $\begin{array}{l}\text { Huge expenditures of time on distance learning of a child, a } \\
\text { lot of time is spent on lessons, a lot of time is spent on } \\
\text { homework, it takes a lot of time to send homework for } \\
\text { verification, the child's life schedule is broken (late waking } \\
\text { up and going to bed), there is not enough time for learning, } \\
\text { the whole the day is spent on lessons, there is no need to } \\
\text { waste time on tutors and hobby groups, there is no need to } \\
\text { waste time on taking the child to and from school. }\end{array}$ & 88 & 23 \\
\hline 22 & Safety & $\begin{array}{l}\text { We are less afraid of being infected with the coronavirus, } \\
\text { the child will not be infected with the coronavirus, we will } \\
\text { wait for vaccination in safety, the consequences of the } \\
\text { coronavirus have not been studied, the child has stopped } \\
\text { getting colds, the risk of accidents at school is lower. }\end{array}$ & 80 & 21 \\
\hline 33 & $\begin{array}{c}\text { Family } \\
\text { load }\end{array}$ & $\begin{array}{l}\text { Excessive educational load on parents, the involvement of a } \\
\text { large number of relatives in the educational process, fatigue } \\
\text { from constant work with the child, parents do not have } \\
\text { enough energy to work and rest due to distance learning at } \\
\text { school. }\end{array}$ & 68 & 18 \\
\hline 44 & Age & $\begin{array}{l}\text { Primary school students are too young for distance } \\
\text { learning, children do not understand online lessons, } \\
\text { children need a teacher, children need live communication, } \\
\text { children miss friends, younger schoolchildren do not know } \\
\text { how to communicate remotely, children miss holidays and } \\
\text { excursions with classmates. }\end{array}$ & 65 & 17 \\
\hline 55 & $\begin{array}{l}\text { The } \\
\text { quality } \\
\text { of } \\
\text { educatio } \\
\text { n }\end{array}$ & $\begin{array}{l}\text { The material is poorly absorbed by the child, online lessons } \\
\text { were rarely conducted, this is a kind of distance learning, } \\
\text { do not like the proposed online platforms, examinations } \\
\text { become profanity, music and physical education lessons do } \\
\text { not need to be carried out remotely, the grades for the } \\
\text { distance quarter do not correspond to the knowledge of } \\
\text { children (over-estimate), online English lessons are } \\
\text { effective, the possibility of better parental control, the child } \\
\text { does not get nervous during testing. }\end{array}$ & 47 & 12 \\
\hline 66 & $\begin{array}{c}\text { Tuition } \\
\text { payment }\end{array}$ & $\begin{array}{l}\text { Payment for lessons with tutors, payment for additional } \\
\text { lessons at school, payment for online courses. }\end{array}$ & 34 & 9 \\
\hline & TOTAL & 380 judgments in 56 interviews & 380 & 100 \\
\hline
\end{tabular}

The main results of the study are reflected in the table with the thematic leitmotifs of the story about distance learning of primary school students during quarantine, most often 
encountered in interviews. With the help of Discant, it was possible to identify six groups of statements. We assigned estimation codes to each group in the mixed fields of Discant. On the one hand, the mixed field allows entering text, on the other, to put one or several numbers characterizing the content of the statement. Here is an example of a judgment from the "Time" group: "During distance learning, the daily routine was broken"/2 - negative assessment. Or: "But then on distance learning, parents and children have enough time to sleep in the morning"/1 - a positive assessment.

As a result of this analysis, it turned out that in the groups "Family load", "Age" there are no statements with a positive attitude to the raised topic. All informants criticize distance education of children. On the contrary, in the "Safety" group, we see only positive assessments. The situation is different in the groups "Time", "Quality of education", "Tuition payment". Here we find positive and negative assessments, as well as neutral judgments.

\section{Advantages and disadvantages of distance education}

Informants talked about distance education of children under quarantine with great excitement. The number of negative assessments of the experience is twice the volume of positive reflection. Nevertheless, there are positive judgments. Thus, the parents tried to minimize the educational losses of the child, using effective digital learning technologies.

4.1. "Time". The leader in terms of the frequency of judgments has become such an important factor in distance education as time. Informants constantly reported on the time spent: how many hours a day were spent on lessons and homework, who of the family representatives was responsible for learning outcomes and invested time in the child, how the family's schedule changed during quarantine. According to 23 informants, a lot of time was spent on distance education, up to 8 hours a day. Parents call such time consumptions losses and consider them too high. According to the respondents, the optimal time spent on distance learning for a child is 4 hours a day. A positive moment in assessing the situation was the additional hours of morning sleep and the saving of time on way to and from school home. Not everyone chose a school close to home, so some families bought time due to distance education.

4.2. "Safety". Predictably, during the pandemic, parents realized that it was safer for children to study at home. Five informants did not believe that the situation required a transfer to distance learning, but they did not deny the risks of infection. Ten parents noted that due to quarantine, the child did not get through the usual spring colds and did not miss a single school day.

4.3. "Family load". In this group we included complaints about family overload, helping children to cope with distance learning. The informants spoke about severe fatigue, inability to do their own work, lack of sleep due to the long preparation of lessons by children, irritation about "double" tasks (class and school work). All reported that the school-related load on family was high before the quarantine, but increased dramatically during distance learning. As for the distribution of responsibilities between representatives of the family, at first the mothers took responsibility for the child's education. Two or three weeks later, the fathers were engaged to help with homework. Among the interviewed families, 14 households lived with their grandparents, 8 grandmothers helped the children with lessons. Older brothers and sisters have become an important family resource for distance learning, since they knew better than their parents in digital educational technologies.

4.4. "Age". In the interviews, the informants paid a significant amount of attention to the age of primary school students. Parents said that third-graders are not able to master the curriculum as independently as required in distance education. Children, unlike secondary and high school students, do not know how to work on a computer, use the Internet, e-mail and messengers. In addition, students in grades 1-4 have an urgent need for direct 
communication with classmates, holding joint holidays, hiking and excursions. Younger school age is the most unsuitable for distance education.

4.5. "The quality of education". The topic of the quality of distance education for primary school students is full of positive and negative assessments, which are divided approximately in half. On the one hand, parents complained about unnecessary lessons (physical education, music). They said that tests lose their meaning when they are done at home, since relatives help the children to do them. On the other hand, the informants liked the opportunity to completely control the child, relieve him of anxiety at the control work, and improve academic performance. In general, parents consider distance education for young schoolchildren to be a form of distance learning, since online lessons were rarely conducted by school teachers. At best, links were given to lessons available on the Internet.

4.6. "Tuition payment". The last place was taken by the topic of monetary expenditures on distance education of children. Expenses were cut down as schools canceled paid classes, sports and dance clubs were closed. Music schools continued their education in a distance format, foreign language classes moved to online platforms. Children from five families continued to study with tutors using Skype and Zoom. The parents were ready to pay for all the remaining lessons, considering the expenses for education of the child a necessary investment in his education.

\section{Conclusion}

The case study identified six leading thematic themes in parenting stories about distance learning for primary school students during quarantine. The main disadvantages of distance education are considered by families to be the enormous load on the schoolchildren' parents, the discrepancy between the methods of distance learning and the age of the students, the low quality of the results of distance learning, and too much time spent by the child and the parents. The advantages of distance learning under quarantine include the safety of the child and family, the freedom and comfort of the life schedule, and innovative methods of education. The practical recommendation of the project is the development of a mixed format for teaching young schoolchildren during a pandemic. Partial transfer of students to distance learning and a decrease in the number of students in the classroom will both reduce the risks of infection and compensate for the loss of educational capital. The empirical perspective of the project is the ongoing analysis of the investments of parents' time in the education of children and the development of new computer programs for the analysis of sociological data. The reported study was funded by RFBR, project number 19-011-00947.

\section{References}

1. R.V. Ryvkina, Social experiment (Novosibirsk, Nauka, 1968)

2. I.A. Khomenko, Public education, 8, 266 (2011)

3. V.S. Sadovskaya, Bulletin of MGUKI, 3(65), 187 (2015)

4. D. Silverman, Sociological research 8, 44 (2019)

5. D.M. Rogozin, Sociological research 10, 120 (2015)

6. Z.V. Proshkova, G.I. Saganenko, M.N. Yashina, 1st International Scientific Conference "Modern Management Trends and the Digital Economy: from Regional Development to Global Economic Growth" (MTDE 2019), Atlantis Press, 694 (2019). doi.org/10.2991/mtde-19.2019.141/

7. V.G. Vinogradskiy, Sociological journal 1-2, 130 (1998)

8. S. Taylor, K. Littleton, Qualitative Sociology Reivew 2(1), 22 (2006) 
9. E. A. Kanevsky, G.I. Saganenko etc., Sociology 4M 9, 198 (1997)

10. A. E. Geger, Sociological Studies 4, 132 (2010)

11. Z. V. Proshkova, G. I. Saganenko, Proceedings of the International Scientific and Practical Conference on Digital Economy (ISCDE 2019), Atlantis Press, 519 (2019) doi.org/10.2991/iscde-19.2019.168 